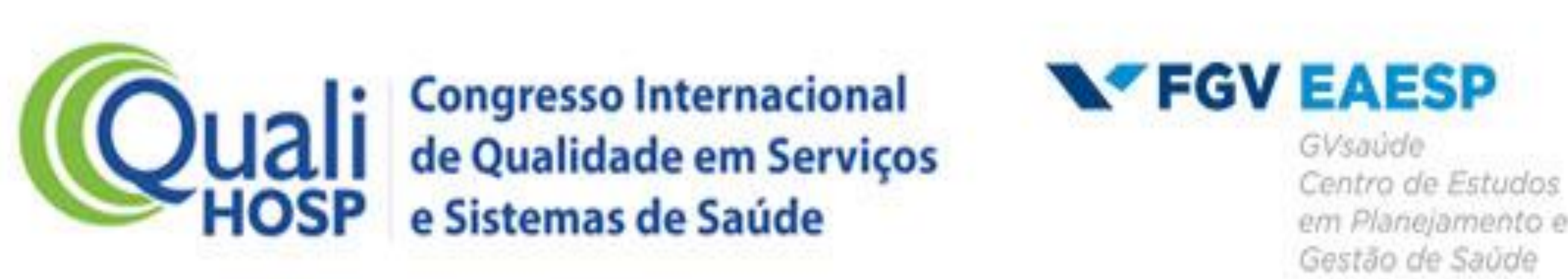

Daiane Aparecida Medeiros, Jucinara Araujo Lima,Patrícia do Prado Costa Braga

Roseli Gomes Cavalini, Sheila Pereira Mendes

\title{
GESTÃO NO REPROCESSO DE MATERIAIS ESTERILIZADOS NA CENTRAL DE MATERIAL E ESTERELIZAÇÃO, GARANTINDO A ESTERILIZAÇÃO E A VALIDADE DỎS PRODUTOS.
}

\author{
Eixo temático: Gestão em Saúde
}

INTRODUÇÃO: Considerado como um grave problema da saúde pública, as infecções hospitalares desafiam as instituições pela busca constante de medidas para a prevenção e controle. Sendo um dos requisitos imprescindíveis para essa prática a garantia da condição de esterilidade e a busca pelo prazo ideal desses produtos.

OBJETIVO: Evidenciar a esterilidade do material após armazenamento por 180 dias embalado no SMS (Spunbond = duas lâminas externas de polipropileno / Meltblown = uma lâmina interna de polipropileno/ Spunbond $=$ duas lâminas externas de polipropileno), diminuir o número de reprocesso por vencimento do produto.

MÉTODO: Trata-se de um estudo retrospectivo com a abordagem quantitativa realizada na central de material e esterilização de um hospital público do alto Tietê. Preparada caixa cirúrgica com instrumentais com 36 peças, submetido à pré - lavagem em água corrente, imerso no detergente enzimático por 5 minutos, realizado limpeza manual e mecânica, secagem com ar comprimido, embalados no SMS submetida a esterilização no vapor sob pressão, após esfriamento foi embalada no cover bag (cobertura de filme plástico), armazenada por 180 dias em local limpo e seco, sob proteção da luz direta, submetida a manipulação mínima com controle de temperatura e umidade.

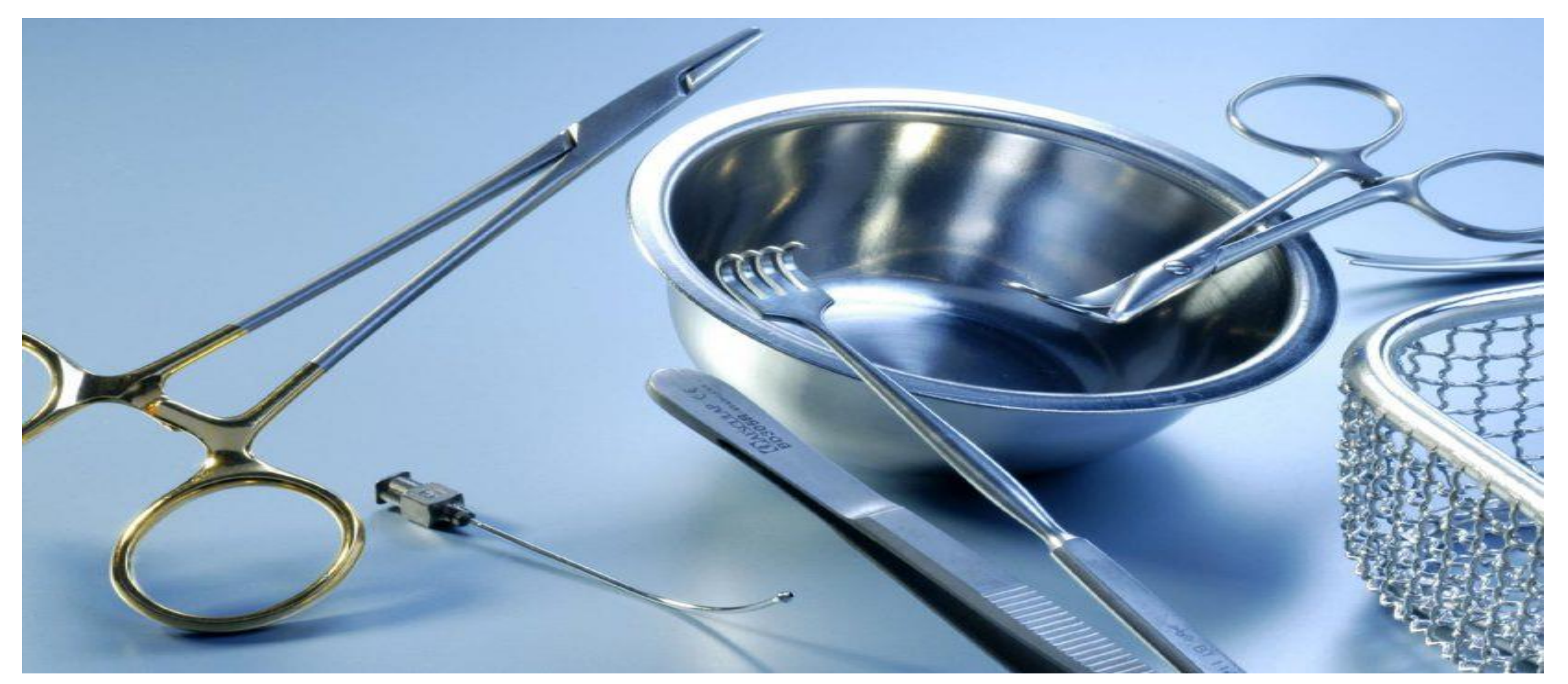

RESULTADOS: Após esse período, o conteúdo da caixa foi submetido a testes de esterilidade em laboratório especialista, evidenciando ausência total de crescimento de microrganismo. O teste foi repetido após seis meses confirmando o mesmo resultado. Realizado discursão com a CCIH (Comissão de controle de infecção hospitalar) e revisado a validade dos materiais esterilizados e embalados no SMS para 180 dias.

CONCLUSÃO: Concluímos que foi possível alteração do tempo de validade de 90 para 180 dias com a redução de 55\% do número de reprocessos de 195 para 88 reprocessos quando comparado 2016 a 2017.

REFERÊNCIAS: GRAZIANO, K. U.; SILVA, A.; PSALTIKIDIS, E. M.(orgs.) Enfermagem em Centro de Material e Esterilização, Barueri, S.P: Manole, 2011. (Série enfermagem). 